\title{
Dividing Precursor Cells of the Embryonic Cortical Ventricular Zone Have Morphological and Molecular Characteristics of Radial Glia
}

\author{
Stephen C. Noctor, ${ }^{1 *}$ Alexander C. Flint, ${ }^{1 *}$ Tamily A. Weissman, ${ }^{3}$ Winston S. Wong, ${ }^{1}$ Brian K. Clinton, ${ }^{3}$ and \\ Arnold R. Kriegstein ${ }^{1,2,3}$ \\ Departments of ${ }^{1}$ Neurology, and ${ }^{2}$ Pathology, and ${ }^{3}$ Center for Neurobiology and Behavior, Columbia College of Physicians \\ and Surgeons, New York, New York 10032
}

\begin{abstract}
The embryonic ventricular zone (VZ) of the cerebral cortex contains migrating neurons, radial glial cells, and a large population of cycling progenitor cells that generate newborn neurons. The latter two cell classes have been assumed for some time to be distinct in both function and anatomy, but the cellular anatomy of the progenitor cell type has remained poorly defined. Several recent reports have raised doubts about the distinction between radial glial and precursor cells by demonstrating that radial glial cells are themselves neuronal progenitor cells (Malatesta et al., 2000; Hartfuss et al., 2001; Miyata et al., 2001; Noctor et al., 2001). This discovery raises the possibility that radial glia and the population of VZ progenitor cells may be one anatomical and functional cell class. Such a hypothesis predicts that throughout neurogenesis almost all mitotically active VZ cells and a substantial percentage of VZ cells overall
\end{abstract}

are radial glia. We have therefore used various anatomical, immunohistochemical, and electrophysiological techniques to test these predictions. Our data demonstrate that the majority of VZ cells, and nearly all mitotically active VZ cells during neurogenesis, both have radial glial morphology and express radial glial markers. In addition, intracellular dye filling of electrophysiologically characterized progenitor cells in the VZ demonstrates that these cells have the morphology of radial glia. Because the vast majority cycling cells in the cortical VZ have characteristics of radial glia, the radial glial precursor cell may be responsible for both the production of newborn neurons and the guidance of daughter neurons to their destinations in the developing cortex.

Key words: radial glia; ventricular zone; neuronal precursor; cortex; development; neurogenesis; cell cycle; electrophysiology
The ventricular zone (VZ) of the embryonic cerebral cortex is a pseudostratified neuroepithelium that contains the precursor cells for most excitatory neurons contributing to the adult neocortex. The initial anatomical descriptions of the cells of the VZ were published over 100 years ago by several pioneering neuroanatomists, including Kölliker, His, Golgi, Magini, and Ramon y Cajal (for review, see Bentivoglio and Mazzarello, 1999). Both Kölliker (1896) and His (1889) showed the existence of a neuroepithelium lining the ventricular system, and Kölliker (1896) also demonstrated, using Golgi impregnations, that cells of this layer possessed long radial fibers that extended into the cortical mantle. Magini (1888b), also using the Golgi method, provided an explicit anatomical description of the neuroepithelial cells of the embryonic cortex: "The cylindrical epithelial cells which cover the ventricular cavity are rather thin $(4-6 \mu \mathrm{m}$ in general), and from each one there escapes a very fine filament which radiates toward the surface of the brain - often I could follow it after it crossed all the thickness ( $3 \mathrm{~mm}$ approximately) of the medullary and cortical substance" (translated from the French). Ramon y Cajal's (1911)

\footnotetext{
Received Dec. 26, 2001; revised Dec. 26, 2001; accepted Jan. 29, 2002.

We thank Dr. David Owens, Dr. Lidija Ivic, Xiaoyan Wang, and Vivek Unni for their helpful comments on this manuscript; Dr. Nathaniel Heintz, Dr. James Goldman, and Dr. Kohichi Nagata for kindly providing antibodies and reagents; and Dr. Fred Gage for kindly providing the retroviral packaging cell line. Dr. Wen-Biao Gan, Dr. Carol Mason, Dr. Anna Dunaevsky, Holly Engelman, Sudhindra Swamy, and Theresa Swayne provided technical assistance and advice. This work was supported by National Institutes of Health Grant NS35710, the Robert Lee and Clara Guthrie Patterson Trust, and the March of Dimes Birth Defects Foundation.

* S.C.N. and A.C.F. contributed equally to this work.

Correspondence should be addressed to Dr. Arnold Kriegstein, Columbia College of Physicians and Surgeons, 630 W. 168th Street, P\&S Building, Room 4-408/ Box 31, New York, NY 10032. E-mail: ark17@columbia.edu.

Copyright (C) 2002 Society for Neuroscience $0270-6474 / 02 / 223161-13 \$ 15.00 / 0$
}

illustrations of embryonic cortex clearly show radial processes extending from the cells of the periventricular neuroepithelium and terminating in branches at the pial surface of the cortex. Ramon y Cajal (1911) also suggested that the reticulated appearance of the "marginal veil," just beneath the pia, resulted from "the interweaving of branches derived from neuroepithelial cells."

Several terms were used by different authors to refer to the radial cells of the periventricular epithelium, including "epithelial cells" (Golgi, 1886; Ramon y Cajal, 1911), "neuroepithelial cells" (Ramon y Cajal, 1911), "ependymal cells" (Retzius, 1894), "spongioblasts" (His, 1889), and "neuroglial cells" (Magini, 1888b). Magini (1888a) was the first to use the term "radial neuroglial cells."

Magini (1888b) observed numerous "varicosities" containing nuclei apposed to the radial fibers of these cells and argued that they represented migrating neurons. Although Ramon y Cajal (1911) agreed that the neuroepithelial cells possessed long radial fibers, he dismissed the idea that newborn neurons migrate along these fibers and postulated instead that the radial fibers serve as general structural support for the developing brain.

Ramon y Cajal (1911) also suggested that neuroepithelial cells were a distinct population from neural progenitors. He supposed that the latter were the round cells with mitotic figures usually observed near the ventricular surface. This proposal agreed with earlier conclusions made by His (1889), who had conceived of separate spongioblast and germinal cell populations. Decades later, however, Sauer (1935) showed that neuroepithelial cells in the CNS undergo a process of interkinetic nuclear migration in which their nuclei descend to the ventricular surface to divide. 
Therefore, the neuroepithelial cells and the mitotic figures at the ventricular surface are not distinct cell populations but represent different cell cycle stages of the same population. Despite the acceptance of this idea, a conceptual distinction has remained between the elongated radial glial cells of the VZ and the population of neural precursor cells.

This conceptual distinction was reinforced by the finding that many but not all mitotic cells in the primate VZ express the glial marker GFAP (Levitt et al., 1981, 1983). The findings that radial cells of the VZ can express GFAP and possess glycogen granules, a glial histologic characteristic (Rakic, 1972; Levitt and Rakic, 1980), supported the idea that these cells are a specialized form of glial cell. Rakic therefore first applied the term "radial glia" (Rakic, 1971a,b), and this appellation is now universally accepted. Radial glia are defined by their characteristic morphology: an endfoot at the ventricular surface, an oval-shaped nucleus found in the VZ or subventricular zone (SVZ), a long radial fiber containing $24 \mathrm{~nm}$ microtubules and $9 \mathrm{~nm}$ intermediate filaments that extends to the "limiting membrane" just below the pia, and abundant glycogen granules in the terminal endfeet near the pia (for review, see Rakic, 1995).

Magini's (1888a,b) original suggestion that newborn neurons migrate along the radial fibers of embryonic epithelial cells was proven correct by Rakic in the 1970s using Golgi impregnation and electron microscopy (Rakic, 1972). Rakic's electron microscopic reconstructions showed that the long radial fibers of primate radial glia have bipolar migrating neurons apposed to them at various levels, showing that radial glia serve as migrational guides for newborn neurons. Subsequently, much work has been done to elucidate the specific molecular interactions underlying the migration of newborn neurons along their radial glial guides (for review see Hatten, 1999).

The finding that the long radial cells of the embryonic cortex are glial cells specialized to subserve neuronal migration was initially interpreted as additional evidence that this population of cells is distinct from the population of neuronal progenitors in the VZ. Glial cells have not been considered previously to be potential neuronal progenitors, and the demonstrated role of radial glia in supporting neuronal migration is consistent with the known role of glia as support cells in the CNS. However, recent evidence from several laboratories showing that radial glia generate neurons has called into question the distinction between radial glia and neuronal progenitors (Malatesta et al., 2000; Hartfuss et al., 2001; Miyata et al., 2001; Noctor et al., 2001; Tamamaki et al., 2001).

Radial glia isolated by several different methods have been shown recently to generate neurons in vitro (Malatesta et al., 2000; Hartfuss et al., 2001). Using in vivo lineage analysis with a green fluorescent protein (GFP)-expressing retrovirus, we have shown recently that radial glial cells are neuronal precursor cells that generate clones of neurons that migrate along parental radial glial fibers (Noctor et al., 2001). In this study, cells labeled in the VZ soon after infection were nearly all radial glia, suggesting that most dividing cells in the VZ are radial glia. Experiments published recently using a GFP-expressing adenovirus and 1,1'dioctadecyl-3,3,3',3'-tetramethylindocarbocyanine perchlorate (DiI) labeling have confirmed that cycling radial glia in the $\mathrm{VZ}$ produce neurons (Miyata et al., 2001; Tamamaki et al., 2001), showing that radial glial infection is not a selective property of the retrovirus used in the above study. Taken together, these data show that radial glia, in addition to being scaffolds for neuronal migration, also serve as neuronal progenitors.
It is unclear whether the production of neurons by radial glial cells represents the rule or exception in neocortical development. If the conceptual distinction between radial glia and precursor cells is incorrect, then most cortical VZ precursor cells may be radial glia. To explore this question we performed a quantitative analysis of the number of radial glial cells located in the cortical VZ. We first used multiple anatomical approaches to determine what proportion of $\mathrm{VZ}$ cells has the defining morphologic features of radial glia. Next, we randomly obtained whole-cell recordings with single-cell dye labeling to determine what percentage of electrophysiologically identified VZ precursor cells has radial glial morphology. Finally, we determined the percentage of dividing VZ cells that express the radial glial markers vimentin (Alvarez-Buylla et al., 1987), 4A4 (Kamei et al., 1998), or RC2 (Misson et al., 1988b) and have fibers reaching the pia. Throughout cortical neurogenesis, our results show that most VZ cells have the morphology of radial glia, that all cells with the characteristic membrane properties of VZ precursor cells appear to be radial glia, and that nearly all dividing VZ cells express radial glial markers and also have radial glial morphology.

\section{MATERIALS AND METHODS}

Immunohistochemistry. Animals used in these studies were maintained according to protocols approved by the Institutional Animal Care and Use Committee at Columbia University. Timed pregnant Sprague Dawley rats (Taconic, NY) at embryonic day (E) 12, E15, and E18 were deeply anesthetized using ketamine and xylazine, and embryos were removed. Embryos at E15 and E18 were perfused transcardially with ice-cold PBS followed by $4 \%$ paraformaldehyde in PBS, and brains were removed, post-fixed overnight in paraformaldehyde, and then stored in PBS at $4^{\circ} \mathrm{C}$. E12 embryos were fixed overnight by immersion, and then brains were removed. Cortical slabs were prepared by dissecting away dorsolateral cortex, opening the lateral ventricle, and removing the hippocampal anlage to expose the ventricular surface. Cryostat sections $(10-30 \mu \mathrm{m})$ were prepared after cryoprotection in $20 \%$ sucrose in PBS and embedding in Tissue-Tek (Sakura, Torrance, CA) before freezing. Immunohistochemistry was performed by rehydration in PBS for $30 \mathrm{~min}$, blocking for $1 \mathrm{hr}(10 \%$ normal goat or horse serum as appropriate, $0.1 \%$ Triton X-100, and $0.2 \%$ gelatin in PBS), washing for $10 \mathrm{~min}$ in PBS, incubation overnight at $4^{\circ} \mathrm{C}$ in primary antibody (dilutions as described below in $2 \%$ normal goat or horse serum as appropriate, $0.1 \%$ Triton $\mathrm{X}-100$, and $0.04 \%$ gelatin in PBS), washing three times for $10 \mathrm{~min}$ in PBS, and incubation in secondary antibody for 1-2 hr (dilutions as described below in $2 \%$ normal goat or horse serum as appropriate, $0.1 \%$ Triton $\mathrm{X}-100$, and $0.04 \%$ gelatin in PBS). For 5-bromo-2'-deoxyuridine (BrdU) immunohistochemistry, an intraperitoneal injection of BrdU (Sigma, St. Louis, MO) $(160 \mathrm{mg} / \mathrm{kg}$ in $0.9 \% \mathrm{NaCl})$ was administered to pregnant rats 1-2 hr before they were killed, cryostat sections were pretreated with $2 \mathrm{~N} \mathrm{HCl}$ in $\mathrm{PBS}$ for $30 \mathrm{~min}$ at $37^{\circ} \mathrm{C}$ before the blocking step, and a fluorescent primary antibody (see below) was used without a secondary antibody step. Primary antibodies were obtained from the following sources and used at the indicated dilutions: fluorescein-conjugated rat monoclonal anti-BrdU (Accurate Chemical; 1:10), mouse monoclonal anti-vimentin (Sigma; 1:40), mouse monoclonal 4A4 (kind gift of Dr. K. Nagata, Aichi Cancer Center Research Institute, Nagoya, Japan; 1:1000), mouse monoclonal RC2 (Developmental Studies Hybridoma Bank; 1:100), guinea pig polyclonal anti-L-glutamate/L-aspartate transporter (GLAST) (gift of Dr. J. Goldman, Columbia University, New York; 1:1000), and rabbit polyclonal anti-brain lipid binding protein (BLBP) (gift of Dr. N. Heintz, Rockefeller University, New York; 1:5000). Secondary antibodies were obtained from the following sources and used at the indicated dilutions: Cy5-conjugated goat anti-mouse (Jackson ImmunoResearch, West Grove, PA; 1:50), Texas Red-conjugated goat anti-mouse (Vector Laboratories, Burlingame, CA; 1:100), Texas Red-conjugated goat anti-rabbit (Vector; 1:100), and rhodamine-conjugated donkey anti-guinea pig (gift of Dr. J. Goldman; 1:1000).

Fluorescent cell staining. Fluorescent labeling of chromatin with Syto-11 or bisbenzamide (Molecular Probes, Eugene, OR) was performed by incubation of sections with $5 \mu \mathrm{M}$ Syto- 11 and $0.1 \%$ DMSO in PBS or $0.001 \%$ bisbenzamide in PBS for 20 min followed by washing three times for $10 \mathrm{~min}$ in PBS. Fluorescent labeling of cell membranes 
with conjugated concanavalin A (ConA) was performed by incubation of sections in $0.02 \mathrm{mg} / \mathrm{ml}$ tetramethylrhodamine- or Alexa Fluor-488conjugated ConA (Molecular Probes), $2 \mu \mathrm{M} \mathrm{CaCl} 2$, and $200 \mu \mathrm{M}$ sodium bicarbonate in PBS for $1 \mathrm{hr}$ followed by washing three times for $10 \mathrm{~min}$ in PBS.

DiOlistic labeling of the VZ with DiI. E12, E15, and E18 brains prepared as above were transferred to PBS containing $0.4 \%$ EDTA for $24-48 \mathrm{hr}$ at $4^{\circ} \mathrm{C}$ and then removed to PBS containing $0.1 \%$ EDTA. EDTA was added to all solutions for DiI (Molecular Probes) experiments to prevent cell-to-cell transfer of the fluorophore (Hofmann and Bleckmann, 1999). For ventricular surface labeling, cortical slabs were dissected as described above. Slabs were placed pial side down in preparation for delivery of DiI. For coronal slice labeling, E18 brains were embedded in low-melting agarose (Fisher Biotech, Fair Lawn, NJ) and sliced coronally at $200 \mu \mathrm{m}$ on a Vibratome (Ted Pella, St. Louis). Cells were labeled with DiI using the recently developed "DiOlistics" method (Gan et al., 2000). A 3\% solution of DiI in methylene chloride (Sigma) was precipitated onto 0.7 $\mu \mathrm{m}$ tungsten microcarriers (Bio-Rad, Hercules, CA). Tefzel tubing (Bio$\mathrm{Rad})$ was then sparsely coated along its inner wall with the prepared microcarriers and cut down to $8 \mathrm{~mm}$ for use as bullets. DiI-coated microcarriers were delivered by gene gun using a 150-200 psi helium pulse. A $3.0 \mu \mathrm{m}$ Isopore membrane filter (Millipore, Bedford, MA) was inserted between the gun barrel and the tissue to reduce delivery of clumped particles. DiI was allowed to diff use throughout the membrane of labeled cells for $24 \mathrm{hr}$ in the dark at $25^{\circ} \mathrm{C}$ in $4 \%$ paraformaldehyde with $0.1 \%$ EDTA. Slabs were then embedded in low-melting agarose (Fisher Biotech), sliced coronally at $250 \mu \mathrm{m}$ on a Vibratome (Ted Pella) for imaging, and stored at $4^{\circ} \mathrm{C}$ in PBS with $0.1 \%$ EDTA. For counting of cells and fiber length analysis, sections were examined on an epifluorescence microscope, and all distinct DiI-labeled cells were followed across focal planes to trace fibers from individual cells. Cells were binned by three independent counters according to radial glial or nonradial glial morphology and fiber length by identifying the borders of the VZ, intermediate zone (IZ), cortical plate (CP), and marginal zone (MZ) on differential interference contrast (DIC) microscopy. Cells were included in the fiber length analysis only if the cell body was located within the VZ and if individual cells and their fibers could be unequivocally identified. Cells with fibers that were transected at the cut edge of the Vibratome section were excluded from analysis. Fibers that became too dim to resolve as they passed deep into the tissue section were binned according to their furthest resolvable point. For the images shown in Figure 3, projections were constructed from confocal $\mathrm{Z}$ stacks (see below), and in some cases neighboring cells in other focal planes were masked for clarity.

Latex microsphere labeling. Cortical slabs were prepared from E18 rats as described above. Fluospheres (Molecular Probes) were painted directly onto the pial surfaces of the slabs, which were maintained for $9 \mathrm{hr}$ at room temperature in artificial CSF (ACSF) that was bubbled continuously with $95 \% \mathrm{O}_{2} / 5 \% \mathrm{CO}_{2}$. BrdU, $20 \mu \mathrm{M}$, was added to the ACSF for the final $2 \mathrm{hr}$. The $9 \mathrm{hr}$ incubation period allowed sufficient time for the latex microspheres to be absorbed and transported throughout those cells with processes reaching the pia. Slabs were fixed overnight in $4 \%$ paraformaldehyde and embedded in $4 \%$ agar, and $100 \mu \mathrm{m}$ coronal sections were cut on a Vibratome. Sections were immunostained with anti-BrdU antibodies, and the tissue was counterstained with fluorescently labeled ConA as described above. Sections were mounted on slides and coverslipped with Aquamount. Serial optical sections obtained at high magnification were taken on an FV300 laser scanning confocal microscope (Olympus). BrdU-labeled soma in the $\mathrm{VZ}$ were then assayed for the presence of Fluospheres. Only those BrdU-labeled cells in which it was possible to discern the entire soma with ConA membrane labeling were included for analysis (see Fig. $5 \mathrm{~A}$, right panel). The use of triple-labeling and confocal microscopy allowed us to confirm colocalization of $\mathrm{BrdU}$ and Fluospheres within individual cells.

Microscopy. Epifluorescence imaging was performed using either a Zeiss Axioskop or an Olympus BX50W I upright microscope and appropriate fluorescence filter sets for fluorescein or rhodamine. Confocal microscopy was performed on a Zeiss LSM410 or LSM510 confocal laser scanning microscope using the following filter sets with the indicated wavelengths (in $\mathrm{nm}$ ) for the excitation laser line and emission filters: fluorescein (green), 488/(510-540); rhodamine (red), 568/(590-610); and Cy5 (far red), 647/(670-810). For double- or triple-staining experiments, the confocal pinhole was set to reduce the depth of optical sectioning as much as possible (always $<3 \mu \mathrm{m}$ ), and the same pinhole setting was used across channels to ensure equal section thickness for the different channels. For imaging of bisbenzamide, dual photon excitation with a Ti:sapphire laser tuned to $770 \mathrm{~nm}$ was used. In some cases, maximum intensity projections were made from $\mathrm{Z}$ stacks (sets of stacked optical sections), but projection data were never used for double- or triple-labeling experiments.

Electrophysiology. Whole-cell recordings from living brain slices were obtained as described previously (Blanton et al., 1989). Briefly, embryos were removed at E17-E18, brains were dissected, and cortical slices were cut coronally at $350-400 \mu \mathrm{m}$ on a Vibratome (Leica). The extracellular ACSF solution contained (in mM): $\mathrm{NaCl} 125, \mathrm{KCl} 5, \mathrm{NaH}_{2} \mathrm{PO}_{4} 1.25$, $\mathrm{MgSO}_{4} 1, \mathrm{CaCl}_{2} 2, \mathrm{NaHCO}_{3} 25$, and glucose $20, \mathrm{pH} 7.4$, at $25^{\circ} \mathrm{C}, 310$ $\mathrm{mOsm} / 1$, and was bubbled with $95 \% \mathrm{O}_{2} / 5 \% \mathrm{CO}_{2}$. Voltage and currentclamp experiments were performed using an EPC-9 patch-clamp amplifier (HEKA Electronic) controlled by a Macintosh computer running Pulse v. 8.0 software (HEKA Electronic). Whole-cell recordings were obtained "blinded" at room temperature from slices that were superfused continuously with $95 \% \mathrm{O}_{2} / 5 \% \mathrm{CO}_{2}$-oxygenated ACSF. Electrodes $(8-12 \mathrm{M} \Omega$ ) were lowered onto the ventricular surface of a cortical slice and slowly advanced until a resistance increase was detected (10-50 $\mathrm{M} \Omega$ ), after which a suction pulse was immediately applied to form a gigaohm seal. To establish whole-cell recording, additional suction was applied to rupture the underlying plasma membrane. Patch electrodes were filled with (in mM): $\mathrm{KCl} 130, \mathrm{NaCl} 5, \mathrm{CaCl}_{2} 0.4, \mathrm{MgCl}_{2} 1$, HEPES 10, pH 7.3, EGTA 1.1, to which $500 \mu \mathrm{M}$ Alexa 594-conjugated biocytin (Molecular Probes) was added to identify recorded cells. Membrane resistance was calculated by measuring the steady-state current deflection during $200 \mathrm{msec}$ voltage steps $( \pm 10-30 \mathrm{mV})$ from a holding potential of $-60 \mathrm{mV}$. $I-V$ relationship was determined by applying $20 \mathrm{msec}$ voltage steps from -80 to $+60 \mathrm{mV}$. Leak-subtracted voltage-clamp recordings in response to voltage steps from -80 to $-10 \mathrm{mV}$ were used to examine the presence of voltage-activated inward currents. Fluorescently labeled cells were subsequently visualized by epifluorescence on an upright, fixed-stage microscope.

Retrovirus production. Replication-incompetent enhanced GFPexpressing retrovirus was produced from a stably transfected packaging cell line (293gp NIT-GFP; gift of Dr. Fred Gage, Salk Institute, La Jolla, CA). Cells were transiently transfected at $\sim 80 \%$ confluence with pVSV-G using the Calphos Mammalian Transfection kit (Clontech, Palo Alto, CA). Supernatant was harvested $48 \mathrm{hr}$ after transfection, filtered through $0.45 \mu \mathrm{m}$ low-protein binding filters (Fisher Scientific), and concentrated 1.000 -fold at $35,000 \mathrm{rpm}, 4^{\circ} \mathrm{C}$ for $1.5 \mathrm{hr}$. Pellets were resuspended in Opti-MEM (Invitrogen, Rockville, MD) and stored at $-80^{\circ} \mathrm{C}$. Final titer of retrovirus was $1 \times 10^{7}$ colony-forming units $/ \mathrm{ml}^{-1}$.

Retrovirus injection. Uterine horns of E17 timed pregnant Sprague Dawley rats were exposed in a sterile biosafety level II hood. Retrovirus $(0.5-1.0 \mu \mathrm{l})$ with Fast Green $(2.5 \mathrm{mg} / \mathrm{ml})$ (Sigma) was injected into the cerebral ventricles through a beveled calibrated glass micropipette (Drummond Scientific, Broomall, PA). After injection, the peritoneal cavity was lavaged with $10 \mathrm{ml}$ of $0.9 \% \mathrm{NaCl}$, the uterine horns were replaced, and the wounds were closed.

Laminar analysis. Postnatal day 6 (P6) pups were anesthetized and transcardially perfused as above. Brains were removed, post-fixed, and sectioned at $100 \mu \mathrm{m}$ on a Vibratome (Ted Pella). Optical sections were collected on a Zeiss 410 laser-scanning confocal microscope, and $\mathrm{Z}$ stack projections were made to analyze the appearance and position of all the GFP-labeled cells. The laminar position of each GFP-positive cell was determined by comparing its normalized distance from the pia with layer position determined from a transmitted light image of the same sections.

\section{RESULTS}

\section{Retroviral infection of radial glia demonstrates postnatal labeling of pyramidal neurons}

We have recently demonstrated that radial glial cells generate radial clones of cortical neurons during embryonic stages of development (Noctor et al., 2001). At $24 \mathrm{hr}$ after infection, 96\% of infected cells in the $\mathrm{VZ}$ are radial glia (Fig. $1 A$ ), and at later time points $(36,48$, and $72 \mathrm{hr}$ ), several clonally related cells, including neurons, are arrayed along the parental radial glial fiber (Noctor et al., 2001). To extend these studies, we examined the postnatal distribution of GFP-labeled cells at stages when most neurons have completed migration and taken up their final laminar position. 

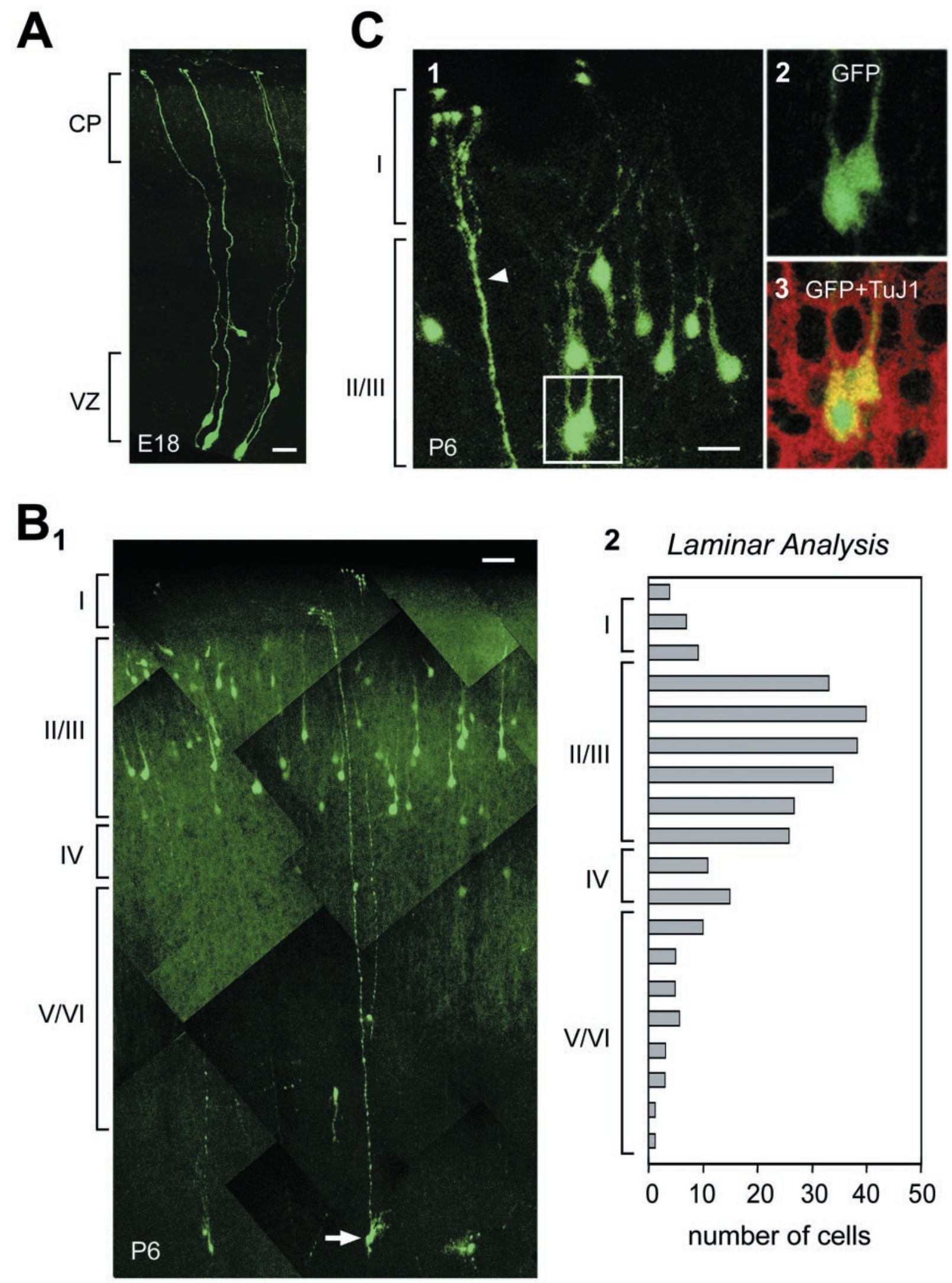

Figure 1. GFP-retroviral labeling at E17 demonstrates radial glia at $30 \mathrm{hr}$ and upper layer cortical neurons at P6. $A$, Representative labeling of radial glia $30 \mathrm{hr}$ after infection. $B_{1}$, At P6, GFP-expressing neurons are distributed mainly in the upper layers of cortex. $B_{2}$, Histogram of the laminar distribution of labeled cells confirms localization to upper cortical layers. $C_{1}$, At P6, many pyramidal-like cortical cells are GFP positive, as are the apical processes of transforming radial glia (arrowhead). $C_{3}$, Optical sections through the GFP-expressing cortical cells shown in $C_{2}$ demonstrate the presence of the neuronal marker TuJ1. Layers I-VI are indicated. Scale bars: $A, 10 \mu \mathrm{m} ; B_{1}, 20 \mu \mathrm{m} ; C, 20 \mu \mathrm{m}$. 
When we analyzed the brains of P6 animals that had been infected at E17, we found a high density of GFP-positive cells concentrated in the upper cortical layers (Fig. $1 B_{1}$ ), as shown by laminar analysis of cell position (Fig. $\left.1 B_{2}\right)\left(\chi^{2} ; p\right.$ value $=6.3 \times$ $\left.10^{-49}\right)$. This result is consistent with the well characterized inside-out pattern of cortical lamination in the postnatal cortex (Angevine and Sidman, 1961), because retroviral labeling at late stages of neurogenesis such as E17 should give rise to neuronal progeny that primarily populate the upper layers of the postnatal cortex. In addition, GFP-labeled pial endfeet of radial glial processes were interspersed among labeled cortical neurons (Fig. $1 C_{1}$, arrowhead). As expected for $\mathrm{P} 6$, the radial glia appeared to be transforming into astrocytes by losing their ventricular endfeet, developing stellate branches, and translocating away from the VZ (Fig. $1 B_{1}$, arrow) (Voigt, 1989; Misson et al., 1991). The GFP-positive cells in the upper cortical layers expressed the neuron-specific marker TuJ1 (Geisert and Frankfurter, 1989), confirming neuronal identity (Fig. $1 C_{3}$ ), and the majority had pyramidal neuron morphology (Fig. $1 B_{1}, C_{1}$ ). It has been suggested recently that pyramidal neurons derive from precursor cells located in the cortical VZ, whereas nonpyramidal neurons are generated elsewhere (Anderson et al., 1997; Mione et al., 1997; Tan et al., 1998; for review see Parnavelas, 2001). Therefore the GFP-positive pyramidal neurons that we observe postnatally (Fig. $1 B, C$ ) may derive from initially infected radial glial precursors observed in the cortical VZ at $24 \mathrm{hr}$ (Fig. 1A). Although we cannot rule out the possibility that some of the GFP-positive cortical cells were generated by precursors in other brain regions and migrated into the cortex, these data are consistent with the concept that radial glia are neuronal precursors in the VZ (Malatesta et al., 2000; Miyata et al., 2001; Noctor et al., 2001). However, these studies do not address whether radial glia represent the predominant precursor cell type or one subset among a larger precursor population during corticogenesis. We therefore sought to determine what proportion of $\mathrm{VZ}$ cells are radial glia.

\section{Simultaneous electrophysiological recording and dye-filling demonstrate that cells with precursor cell physiology are radial glia}

Previous studies using whole-cell recording techniques have described the characteristic physiological properties of cycling precursor cells in the embryonic cortical VZ (LoTurco and Kriegstein, 1991; LoTurco et al., 1995; Bittman et al., 1997). These precursor cells have a low membrane resistance caused by extensive gap-junction coupling and a relative absence of voltage-gated inward conductances. Previous whole-cell recording studies used gap junction-permeable dyes to confirm the extensive coupling of this cell population (LoTurco and Kriegstein, 1991; Bittman et al., 1997). To characterize the morphology of individual electrophysiologically identified VZ precursor cells, we labeled cells intracellularly using electrodes filled with Alexa-594-conjugated biocytin, a fluorescent dye that does not readily pass through gap junctions. Whole-cell recordings were randomly obtained from VZ cells in coronal slices from E12 to E19, ages that span both early and late stages of neurogenesis in the rat cortex. Recordings were made by advancing electrodes into the ventricular surface using the blind technique (Blanton et al., 1989), an approach used in previous studies to characterize $\mathrm{VZ}$ precursor cell physiology (LoTurco and Kriegstein, 1991; Bittman et al., 1997). This method selects cells that have an endfoot contacting the ventricular surface, thus allowing for recordings from precursor cells in the VZ but only rarely from postmitotic neurons.
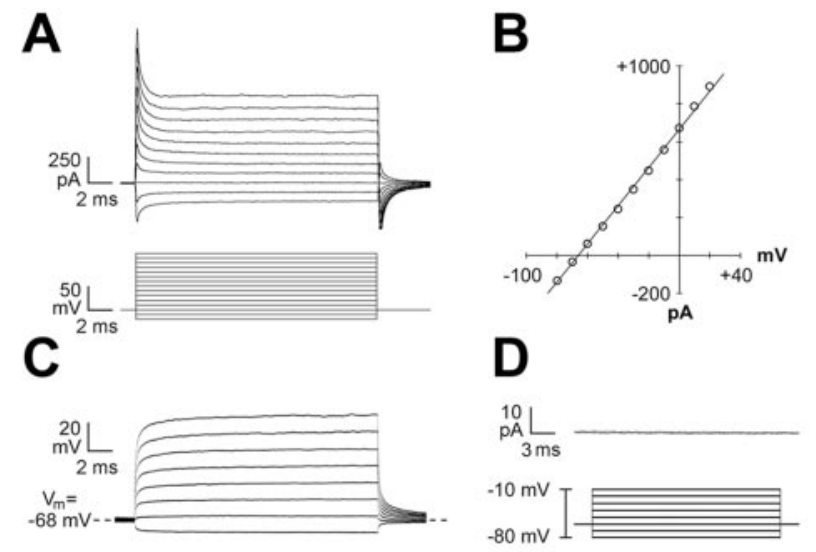

E

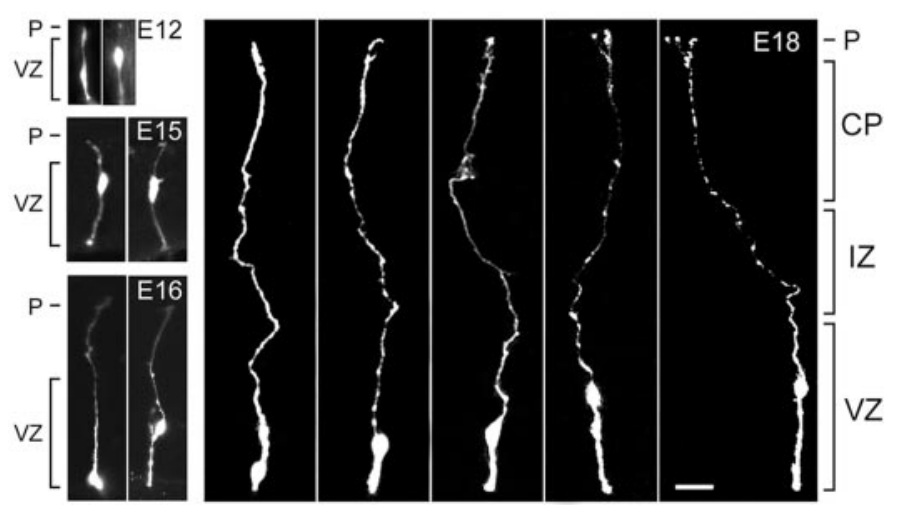

Figure 2. All recorded cells had the expected physiological properties of precursor cells. $A$, Typical recordings of current responses to a series of voltage steps in voltage-clamp mode demonstrate low input resistance. $B$, Current-voltage is linear between $-90 \mathrm{mV}$ and $+10 \mathrm{mV}$ in the same cell as $A$. C , Current responses to a series of voltage steps recorded in current-clamp mode. $D$, Leak-subtracted voltage-clamp recordings confirm the absence of voltage-gated sodium conductances. $E$, Representative cells recorded and filled at E12,E15, E16, and E18. Five representative recorded cells shown at E18 exhibit radial glial morphology, with an endfoot on the ventricle, a cell body within the VZ, and a radial process extending to the pia $(P)$. Scale bar, $10 \mu \mathrm{m}$.

The mean resting membrane potential of recorded cells ranged from -57.1 to $-77.6 \mathrm{mV}$ at all ages $(n=102$ cells $)$. The recorded cells had the expected physiological properties of precursor cells: input resistance was low (mean of $138.6 \pm 6.9 \mathrm{M} \Omega ; n=102$ ) (Fig. $2 A$ ), and the current-voltage relationship was linear between -90 $\mathrm{mV}$ and $+10 \mathrm{mV}$ (Fig. $2 B$ ), demonstrating a lack of voltage-gated sodium conductances (Fig. $2 B$ ). Current steps in current-clamp mode (Fig. 2C) and leak-subtracted voltage-clamp recordings (Fig. 2D) confirmed the absence of voltage-gated sodium conductances. Input resistance increased as a function of age from $106.0 \pm 16.5 \mathrm{M} \Omega$ at $\mathrm{E} 12$ to $180.6 \pm 38 \mathrm{M} \Omega$ at E19, consistent with the known decrease in coupled cluster size during cortical development (LoTurco and Kriegstein, 1991).

In all cases $(n=102 / 102)$, the recorded cell exhibited radial glial morphology, with an endfoot on the ventricle, a cell body within the VZ, and a radial process extending toward the pia. As the cortical mantle expanded from E12 to E19, the radial fibers of recorded precursor cells lengthened to span the entire thickness of the cortical mantle regardless of developmental age (Fig. 2E). Specifically, at late stages (E18, E19), when a thickened IZ 
separates the pia from the VZ and one can unambiguously identify radial glial morphology, filled radial fibers extended to the pia $(n=60 / 61)$ or CP $(n=1 / 61)$ (Fig. $2 E)$. These results show that cells with the membrane properties of precursor cells have the morphology of radial glia.

\section{Random DiOlistic labeling demonstrates anatomically that most of the VZ cells are radial glia}

The VZ is a pseudostratified neuroepithelium where all cells, with the exception of postmitotic neurons, contact the ventricular surface (Sauer, 1935). To characterize the morphology of VZ cells, we randomly labeled VZ cells contacting the ventricle with the recently developed DiOlistics technique (Gan et al., 2000). Small DiI-coated tungsten beads were delivered via gene gun to the ventricular surface of intact fixed cortical slabs, and the DiI was allowed to diffuse throughout the membrane of individual cells (see Materials and Methods). This labeling technique allowed us to analyze individual VZ cell morphology and quantify the number of cells with radial glial features.

DiOlistics experiments were performed at E12, E15, and E18. Previous observations have shown that radial glial fibers sometimes terminate in the marginal zone, cortical plate, or upper intermediate zone (Gadisseux et al., 1992). Therefore, our criteria for radial glia included a cell body in the VZ, a ventricular endfoot, and a radial process extending out of the $\mathrm{VZ}$ and into the MZ, CP, or upper IZ. At E18 the cortical plate and intermediate zone are relatively thick, and these regions can be distinguished easily. Most of the cells labeled by this method at E18 (86.6 \pm $4.5 \% ; n=21$ slices; 799 cells) (Fig. $3 E$ ) had distinct radial glial morphology (Fig. $3 A, B$ ) with a radial process extending either to the $\mathrm{CP} / \mathrm{MZ}(60.4 \pm 4.0 \%)$ or the upper IZ $(26.2 \pm 3.6 \%)$ (Fig. $3 B)$. In our tissue labeled from the ventricular surface, long fibers become progressively dimmer as they approach the pia. We measured fiber length based on the furthest resolvable point and rarely observed abrupt fiber terminations in the IZ. Therefore our counts most likely under-represent actual fiber length. We observed a smaller percentage of VZ cells $(13.4 \pm 4.5 \%)$ that had processes restricted to the VZ (Fig. 3C). This latter group of cells may include newborn neurons, as one would expect (Takahashi et al., 1996; O'Rourke et al., 1997), or other cells with short processes.

To examine the morphology of VZ cells at earlier ages, we also performed ventricular surface DiOlistic labeling at E12 and E15. At E15 the VZ is separated from the pia only by the marginal zone, because the cortical plate has yet to develop (Boulder Committee, 1970). Most VZ cells labeled with DiOlistics at E15 had a process that spanned nearly the entire thickness of the cortical mantle, to the upper marginal zone or pia $(84.8 \pm 3.1 \%$; $n=28$ slices; 788 cells) (Fig. $3 D)$. The remainder $(15.2 \pm 3.1 \%)$ had processes restricted to the VZ. At E12, because the neuroepithelium spans the entire cortical width (Altman and Bayer, 1990), virtually every cell labeled from the ventricular surface contacted the pial surface.

To control for potential bias that could be introduced in ventricular surface labeling if there is a nonrandom distribution of endfoot size among cell classes, we also performed DiOlistics on the cut surface of coronal sections of E18 cortex. In these experiments, $70.1 \pm 4.9 \%$ of cells with a soma in the $\mathrm{VZ}$ were radial glia, whereas $29.9 \pm 4.9 \%$ were VZ-restricted cells $(n=6$ slices; 187 cells). The increased number of nonradial glial cells in the VZ in these experiments was primarily accounted for by an increase

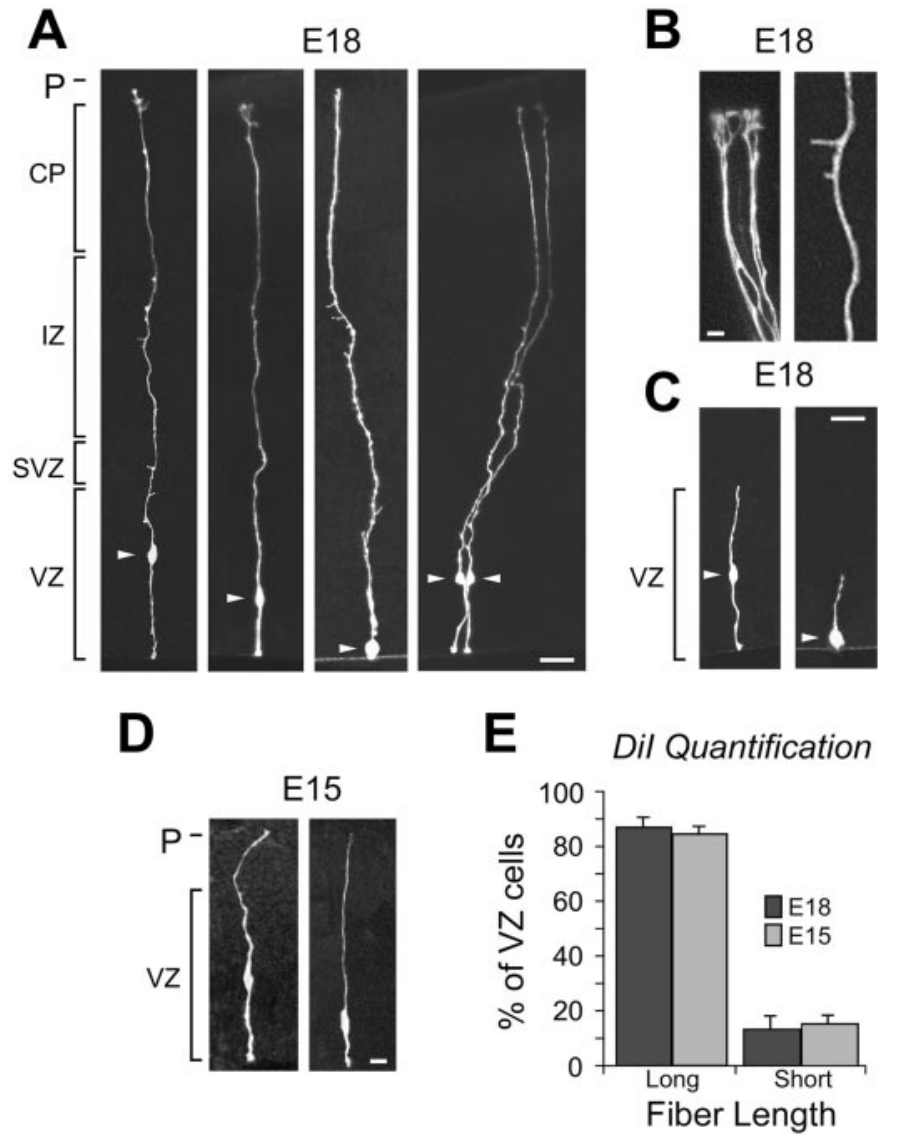

Figure 3. Random labeling of VZ cells by DiOlistics suggests that most of the VZ cells are radial glia. $A$, Shown are labeled cells at E18 with somata (arrowheads) in the upper, middle, and lower zones of the VZ and long fibers extending to the pia. $B$, Cells identified by DiOlistic labeling have expected morphological features of radial glial cells, such as branched pial endfeet of the long radial fiber (left) and small side branches (right). C, A small percentage of cells with processes restricted to the VZ are also observed, with cell bodies (arrowheads) in the middle (left) and lower (right) zones of the VZ. D, The majority of VZ cells labeled by DiOlistics at E15 resembled these two examples with long radial fibers. $E$, Quantitative analysis of the percentage of cells with long pially directed fibers (Long) versus cells with fibers restricted to the VZ (Short) identified by random DiOlistic labeling of the VZ surface at E15 and E18. Scale bars: $A, C, 10 \mu \mathrm{m} ; B, D, 5 \mu \mathrm{m}$. $C P$, Cortical plate; $I Z$, intermediate zone; $P$, pia; $S V Z$, subventricular zone.

in cells lacking a contact on the ventricular surface that had the morphology expected of newborn neurons.

Taken together, the results of our electrophysiological and DiOlistics experiments show that most of the VZ cells identified either physiologically or anatomically have radial glial morphology. The nonradial glial cells labeled by both approaches likely included newborn neurons, but on the basis of these data we cannot rule out the possibility that some of these cells represent a distinct population of cycling progenitor cells. We therefore performed a series of experiments to further characterize the VZ by examining the characteristics of mitotically active VZ cells.

\section{VZ cells in S-phase express the radial glial markers vimentin and $\mathrm{RC2}$}

Neuronal precursors in the embryonic VZ undergo a process of interkinetic nuclear migration in which cells pass through $S$-phase of the cell cycle with their nuclei in the outer half of the VZ and then enter M-phase along the border of the lateral ventricle 
(Sauer, 1935). To assess what percentage of S-phase cells in the $\mathrm{VZ}$ are radial glia, we labeled S-phase cells in utero at three ages spanning the neuronogenetic interval (E12, E15, and E18) and determined what percentage of S-phase cells at these ages express radial glial markers. Pregnant rats received a single injection of BrdU and were killed 1-2 hr later. VZ cells were labeled with an antibody to the radial glial marker, vimentin, an intermediate filament protein that has been shown to specifically label radial glial cells in the cortex at the ages used here (Dahl et al., 1981; Pixley and de Vellis, 1984; Kalman and Ajtai, 2001). Vimentin labeling is localized to the cytoplasm, whereas the BrdU label is limited to the nucleus. To ensure that individual doublelabeled cells were identified correctly, we used a third marker, tetramethylrhodamine-conjugated ConA, to label cellular membranes (Tarasova et al., 1997), thereby outlining individual cells. We used confocal microscopy to visualize all fluorescent labels in the same optical section. The use of this triple-labeling and imaging protocol allowed us to confirm colocalization of BrdU and vimentin immunolabeling in individual cells (Fig. $4 A_{2}$ ).

As shown in Figure $4 A_{1}$, vimentin is expressed in the vast majority of BrdU-positive VZ cells. To limit counting of newborn neurons that might have exited the cell cycle between the injection of BrdU and the time rats were killed, we counted only BrdU-positive cells in the outer half of the VZ, where S-phase nuclei reside. At E12, $99.3 \pm 0.3 \%$ of cells labeled with BrdU in the S-phase zone were positive for vimentin ( $n=13$ sections; 548 cells). At E15, the percentage was $98.6 \pm 0.5 \%(n=7$ sections; 564 cells $)$, and at E18, the percentage was $98.3 \pm 0.4 \%(n=9$ sections; 539 cells).

To confirm these data, we also performed a quantitative analysis of the colocalization of BrdU and vimentin labeling in dissociated VZ cell suspensions to unequivocally identify individual cells. In these experiments, $94.5 \%(n=310$ cells $)$ of BrdU-labeled cells were vimentin positive (Fig. $4 B$ ). These data demonstrate that most of the proliferative VZ cells in S-phase express the radial glial marker vimentin throughout neocortical neurogenesis.

We repeated these experiments in mouse using the murine radial glial-specific marker RC2 (Misson et al., 1988b). S-phase VZ cells were pulse labeled with BrdU in E15.5 mice (roughly equivalent to E18 in the rat), and mice were killed 1-2 hr later. We then labeled radial glia with antibodies to RC2 and determined the percentage of BrdU-labeled cells that were RC2 positive. RC2 densely labeled the entire VZ (Fig. $\left.4 C_{1}, C_{2}\right)$ and appeared qualitatively identical to vimentin staining in the rat. As in the vimentin double-labeling experiments described above, we used concanavalin-A to confirm colocalization of the markers within VZ cells. We found that in E15.5 mice, $96.1 \pm 0.8 \%(n=$ 5 sections; 342 cells) of the BrdU-positive VZ cells were positive for RC2. We also dissociated BrdU-labeled mouse cortical cells and stained them with RC2 to unambiguously calculate the percentage of BrdU cells that also expressed RC2. We found that 97\% (233/239) of dissociated BrdU-positive cells coexpressed RC2 (Fig. 4D). In addition we stained embryonic brain slices using antibodies against BLBP (Feng et al., 1994) and the astrocyte-specific glutamate transporter, GLAST (Shibata et al., 1997), both of which are proteins expressed in subsets of radial glial cells (Hartfuss et al., 2001). In cortical regions where these markers are expressed, $93.0 \pm 2.7 \%$ ( $n=5$ sections; 204 cells $)$ of BrdU-positive cells were positive for BLBP and 95.4 $\pm 0.3 \%(n=$ 4 section; 313 cells) of BrdU-positive cells were positive for
GLAST. These data indicate that the vast majority of S-phase cells in the embryonic VZ express a range of radial glial markers.

\section{VZ cells in S-phase have fibers that extend to the pia}

If S-phase cells are radial glia, they should have characteristic radial glial fibers that extend to the pial surface. To examine this morphological feature of S-phase VZ cells, we applied fluorescently labeled latex microspheres (beads) to the pial surface of acute cortical slabs. The slabs were incubated for $9 \mathrm{hr}$ to allow retrograde labeling of those cells in the $\mathrm{VZ}$ with processes contacting the pia (Katz et al., 1984), and BrdU was added during the final $2 \mathrm{hr}$ to label S-phase cells. Slabs were then fixed, and coronal slices were examined to quantify the number of BrdU-positive cells in the VZ that contained fluorescent beads. All sections were counterstained with ConA to label cell membranes and outline individual VZ cells. With this triple-staining protocol, and the use of serial confocal sectioning, we were able to unambiguously identify VZ cell somata that contained beads (Fig. $5 A$ ).

After pial application of fluorescent beads, we found that the beads retrogradely labeled VZ cells in regions underlying the pial painting, whereas neighboring regions of $\mathrm{VZ}$ remained unlabeled (Fig. 5A, middle panel). When we examined serial optical sections, we found that $90.5 \pm 2.5 \%$ ( $n=11$ sections; 658 cells $)$ of BrdU-positive VZ cells contained beads in their perinuclear cytoplasm (Fig. 5A, right panel). It is likely that this number under-represents the actual percentage of bead-labeled VZ cells, because in the optical sections we could only examine the BrdUlabeled cell body and not the endfeet or radial fibers of VZ cells. Therefore, we could not determine whether cells without perinuclear beads contained beads in their processes. These data indicate that in addition to expressing radial glial markers, most VZ cells in S-phase have radial processes extending to the pia. To examine cycling VZ cells at a different stage in the mitotic cycle, we next analyzed the expression of phosphorylated vimentin in cells undergoing M-phase at the ventricular surface.

\section{VZ cells in M-phase express $4 A 4$, a specific marker for dividing radial glia}

Vimentin is phosphorylated by the cell cycle kinase cell division cycle 2 (cdc2) in radial glial cells during cytokinesis (Kamei et al., 1998). An antibody raised against the cdc 2 phosphorylation site on vimentin, termed $4 \mathrm{~A} 4$, has been shown to specifically label radial glia in M-phase (Kamei et al., 1998). We used 4A4 immunohistochemistry to determine what percentage of $\mathrm{VZ}$ cells in M-phase are radial glia. We stained coronal sections and intact cortical slabs with the 4A4 antibody and then labeled all cell nuclei using the fluorophore Syto-11. Using this approach, all M-phase cells at the ventricular surface can be clearly identified morphologically by their condensed chromatin and arrangement of chromatin into mitotic figures. As shown in Figure $5 B$, confocal imaging of intact neocortex from the ventricular surface revealed Syto-11-labeled cells in various stages of M-phase (arrows). All of these Syto-11-labeled mitotic figures (Fig. 5B, green) are surrounded with positive immunolabeling for $4 \mathrm{~A} 4$ (Fig. 5B, red). Other cells in the field without condensed chromatin (Fig. $5 B$, arrowheads) are negative for 4A4. Cells in specific stages of M-phase - metaphase, anaphase, and telophase - could be identified in both coronal sections and intact cortical slabs, as shown in Figure $5 C$. As shown previously for 4A4 immunostaining (Kamei et al., 1998), positive staining is found almost exclusively in cells with nuclei along the ventricular border (Fig. 5D), where $\mathrm{VZ}$ precursor cells undergo M-phase. To determine what per- 


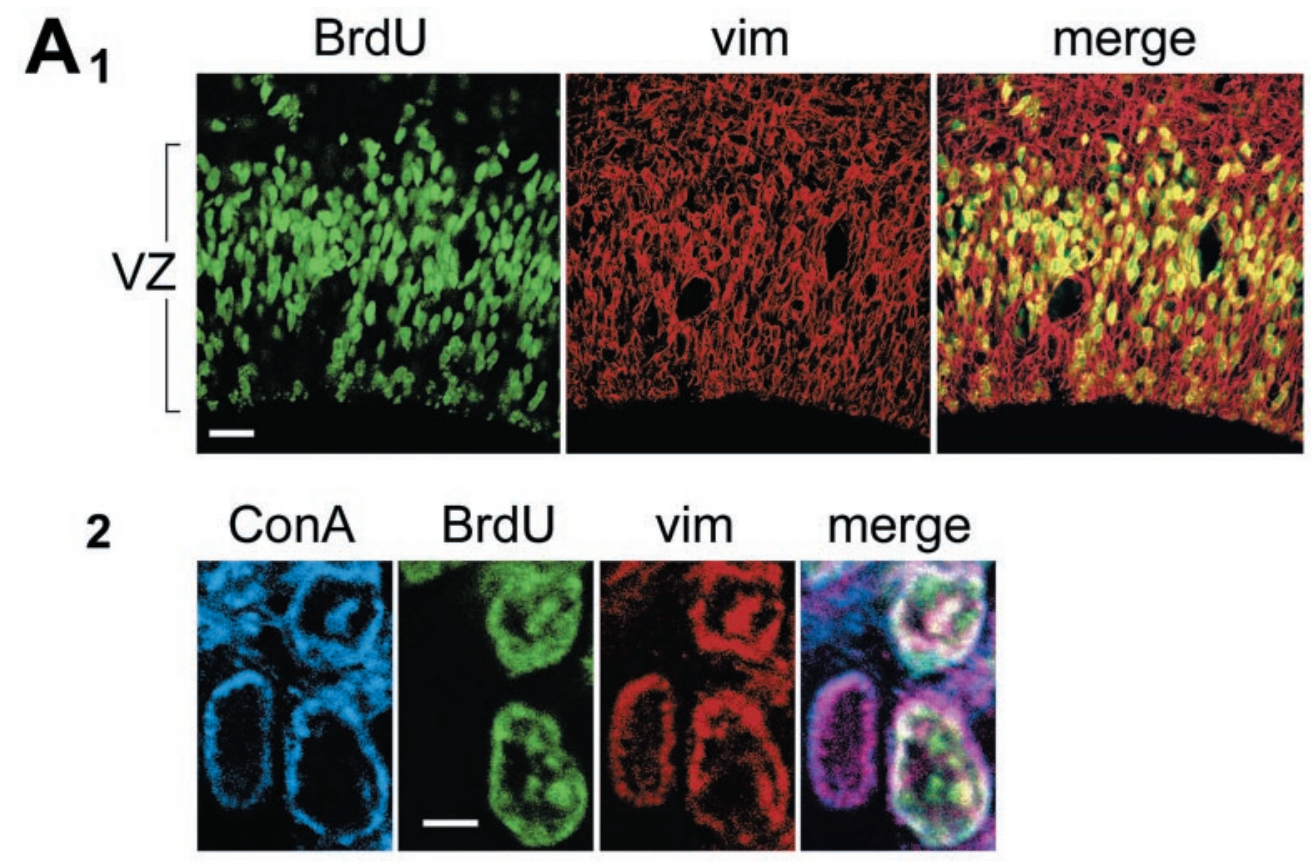

Figure 4. S-phase cells in the VZ express the radial glial markers vimentin and RC2. $A_{1}, \operatorname{BrdU}$ labeling (BrdU, green) in E18 rat tissue fixed $1 \mathrm{hr}$ after BrdU injection to identify S-phase cells. Vimentin labeling (vim, red) labels most cells in the VZ. Overlay of the two channels is shown in the right panel (merge). $A_{2}$, Colocalization of BrdU and vimentin labeling in brain slices was confirmed using a third marker, concanavalin A (ConA, blue) to label cellular membranes. Overlay of the BrdU, ConA, and vimentin channels is shown on the right (merge). B, BrdU-positive dissociated single cells are also vimentin positive. Some cells (arrows in DIC panel) do not express either marker, and some vimentin-positive cells do not express BrdU (arrowheads). $C_{1}$, In E15 mouse brain slices, BrdU (green) colocalizes with the murine radial glial marker, RC2 (red). $C_{2}$, Colocalization of $\mathrm{BrdU}$ and RC2 was determined at higher magnification than in $C_{1}$, as shown here. $D$, BrdU-positive dissociated single cells are also RC2 positive. Scale bars: $A, C, 15$ $\mu \mathrm{m} ; B, 5 \mu \mathrm{m} ; D, 20 \mu \mathrm{m}$.
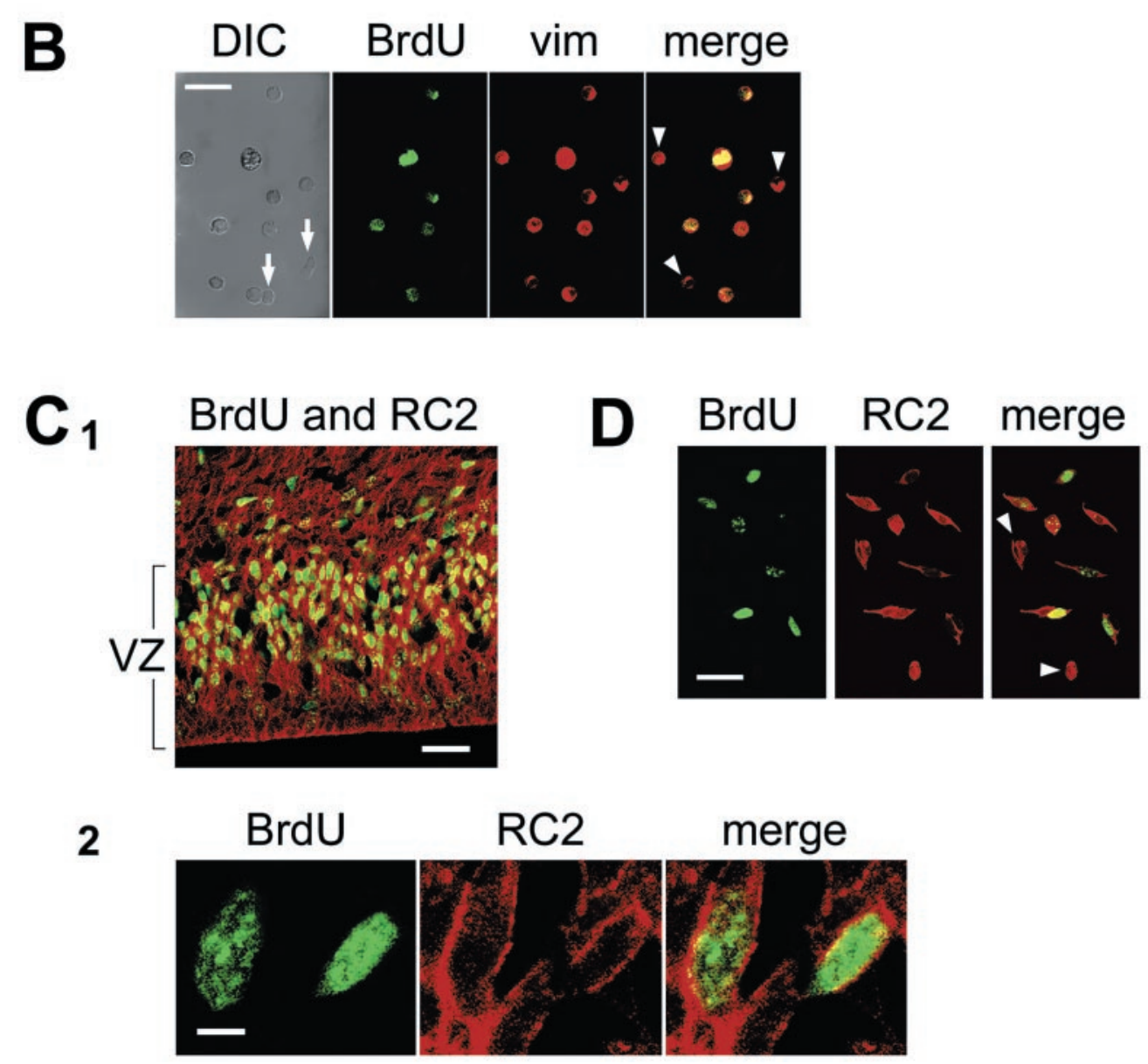

centage of M-phase cells express 4A4, we performed quantitative analysis in coronal sections. To conservatively identify M-phase cells for quantification, we counted only cells in anaphase and telophase, stages that could be easily and unambiguously identi- fied (Fig. 5C). Results were virtually identical at the ages studied. At E12, $98.7 \pm 0.1 \%$ of anaphase and telophase cells lining the VZ surface were positive for 4A4 ( $n=3$ brains; 551 cells). At E15, this percentage was $98.3 \pm 0.3 \%$ ( $n=3$ brains; 555 cells), 
and at E18, this percentage was $98.8 \pm 0.1 \%(n=3$ brains; 597 cells). Therefore, consistent with our data for vimentin expression in S-phase cells, virtually all M-phase cells in the VZ express the radial glial-specific marker 4A4 throughout development.

Because low levels of $4 \mathrm{~A} 4$ staining were also present within the cytoplasm of labeled cells, we were able to examine the morphology of M-phase VZ cells to determine whether they resembled radial glia. It has been shown recently that dividing radial glial cells retain their radial fibers even through $\mathrm{M}$-phase of the cell cycle (Miyata et al., 2001); thus we are able to ask whether mitotic VZ cells have radial processes characteristic of radial glial cells. We found that dividing cells often had 4A4-positive radial processes extending from the $\mathrm{VZ}$ to the marginal zone (Fig. $5 D_{2}$ ).

To examine whether $4 \mathrm{~A} 4$ is specific for dividing radial glial cells and not ubiquitously expressed in dividing cells in the brain, we also examined 4A4 staining in sections of P8 cerebellum. At this stage of cerebellar development, significant numbers of granule cells are dividing in the external granule cell layer (EGL) where radial glia are not found. In contrast, a population of cerebellar radial glial cells, the Bergmann glia, have their nuclei at the top of the inner granule cell layer (Hatten and Heintz, 1995). In P8 cerebellum, specific 4A4 immunoreactivity was found in some Bergmann glial cells, but not in mitotic cells in the EGL (Fig. 5E), consistent with previous data that 4A4 is specific for dividing cells of the radial glial lineage (Kamei et al., 1998).

\section{DISCUSSION}

\section{Precursor cells in the VZ are radial glia}

The cortex develops from a proliferative neuroepithelium that initially spans the entire cortical mantle and thickens progressively during neurogenesis. During this process, radial glia contact the ventricle and elongate their apical fibers far beyond the upper border of the VZ. A distinction has traditionally been made between radial glia that extend processes to the pia and neural precursor cells that are believed to be restricted to the VZ. However, these two cell populations actually share a number of common features, including interkinetic nuclear migration during the cell cycle (Misson et al., 1988a), expression of the neural precursor marker nestin (Hockfield and McKay, 1985; Lendahl et al., 1990), and a characteristic radial morphology with endfeet contacting the ventricular surface (Sauer, 1935). These common features, together with evidence that cortical radial glia generate neurons (Malatesta et al., 2000; Noctor et al., Miyata et al., 2001; 2001), raise the possibility that neuronal precursor cells and radial glia may represent overlapping populations of VZ cells. Furthermore, the population of neuronal precursors that are presumed to be distinct from radial glia has not been clearly characterized.

We find here that most of the cycling VZ cells have morphological, molecular, and physiological characteristics of radial glia. We first specifically examined VZ cells that had characteristic membrane properties of precursor cells and found that they have radial glial morphology. We next randomly labeled $\mathrm{VZ}$ cells using the DiOlistics technique and found that most exhibit radial glial morphology, including ventricular endfeet, lamellate projections that frequently contact blood vessels, and radial processes with branched endings on the pia. Because postmitotic neurons are generated by cell divisions at the ages we studied, we next examined mitotic VZ cells at specific stages in the cell cycle to determine whether they have radial glial characteristics. We labeled S-phase cells using BrdU and found that most of the proliferating cells express the specific radial glial markers vimentin, RC2, BLBP, and GLAST. Colabeling of M-phase cells with
Syto-11 and 4A4 confirmed that dividing VZ cells also express the phosphorylated form of the radial glial-specific marker vimentin. Moreover, visualization of phosphorylated vimentin within the long radial processes of $\mathrm{M}$-phase cells directly demonstrated that dividing VZ cells have radial glial morphology. Finally, pial application of fluorescent microspheres led to labeling of $90 \%$ of VZ cells in S-phase, indicating that most cycling VZ cells have processes that reach the pia. Therefore, most VZ cells overall have radial glial morphology and virtually all proliferating VZ cells both express specific radial glial markers and have fibers that span the cortex. Throughout the period of neuronal production, we do not find evidence for a nonradial glial population of dividing VZ precursor cells. Therefore, we propose that most precursor cells in the embryonic ventricular zone are radial glial cells.

Radial glia have traditionally been classed as specialized glial cells with a unique developmental role in guiding neuronal migration (Rakic, 1988). Recent data, however, indicate that radial glia serve dual roles as both neuronal precursors and migrational guides (Alvarez-Buylla et al., 1990; Malatesta et al., 2000; Noctor et al., 2001), suggesting that there may be no appropriate distinction between radial glia and neuronal progenitors in the VZ (Alvarez-Buylla et al., 2001; Parnavelas and Nadarajah, 2001). We show here that nearly all mitotically active VZ cells appear to be radial glia. Taken together with recent evidence that radial glial cells generate neurons, the data presented here raise the possibility that radial glia may be the predominant neuronal precursor cells in the embryonic neocortical VZ.

\section{Are radial glia, glia?}

If radial glial cells are to be considered neuronal precursors, is it appropriate to term them "glia"? In the late 19th century, it was thought that most, if not all, neuroepithelial cells in the cortex extend a long radial process across the cortical mantle (Magini, 1888b; Kölliker, 1896). In today's nomenclature, these cells would be called radial glial cells. It has been presumed that these cells are differentiated support cells committed to the glial lineage, in part because they were shown to express the astrocyte marker GFAP and possess glycogen granules (Rakic, 1972; Levitt and Rakic, 1980). Glial cells specialized to guide neuronal migration (Rakic, 1978; Schmechel and Rakic, 1979a; Levitt and Rakic, 1980) were not believed to be capable of producing neurons as well. However, it is now clear that these cells are multipotential. Therefore, it may now be timely to reconsider the general nature of radial glial cells. Radial glia have many features in common with astrocytes beyond common expression of molecular markers such as glial filaments. For example, both cell types make specialized contacts with blood vessels (Chanas-Sacre et al., 2000), contain glycogen storage granules (Rakic, 1972; Bruckner and Biesold, 1981), are coupled together with gap junction channels (Massa and Mugnaini, 1982; LoT urco and Kriegstein, 1991), and sustain intracellular calcium waves (T. A. Weissman and A. R. Kriegstein, unpublished observations). In addition, radial glial cells are known to transform into astrocytes. Thus it is seems appropriate to consider radial glia a form of glial cell. However, because astrocytes and radial glia can generate neurons (Doetsch et al., 1999; Malatesta et al., 2000; Noctor et al., 2001; Seri et al., 2001), the radial glial cell can be considered less a specialized glial cell and more a precursor cell with glial characteristics and the potential to generate cells of both neuronal and glial lineages. This formulation recalls the concept of the "radial neuroglial cells" described by Magini in the 19th century. 

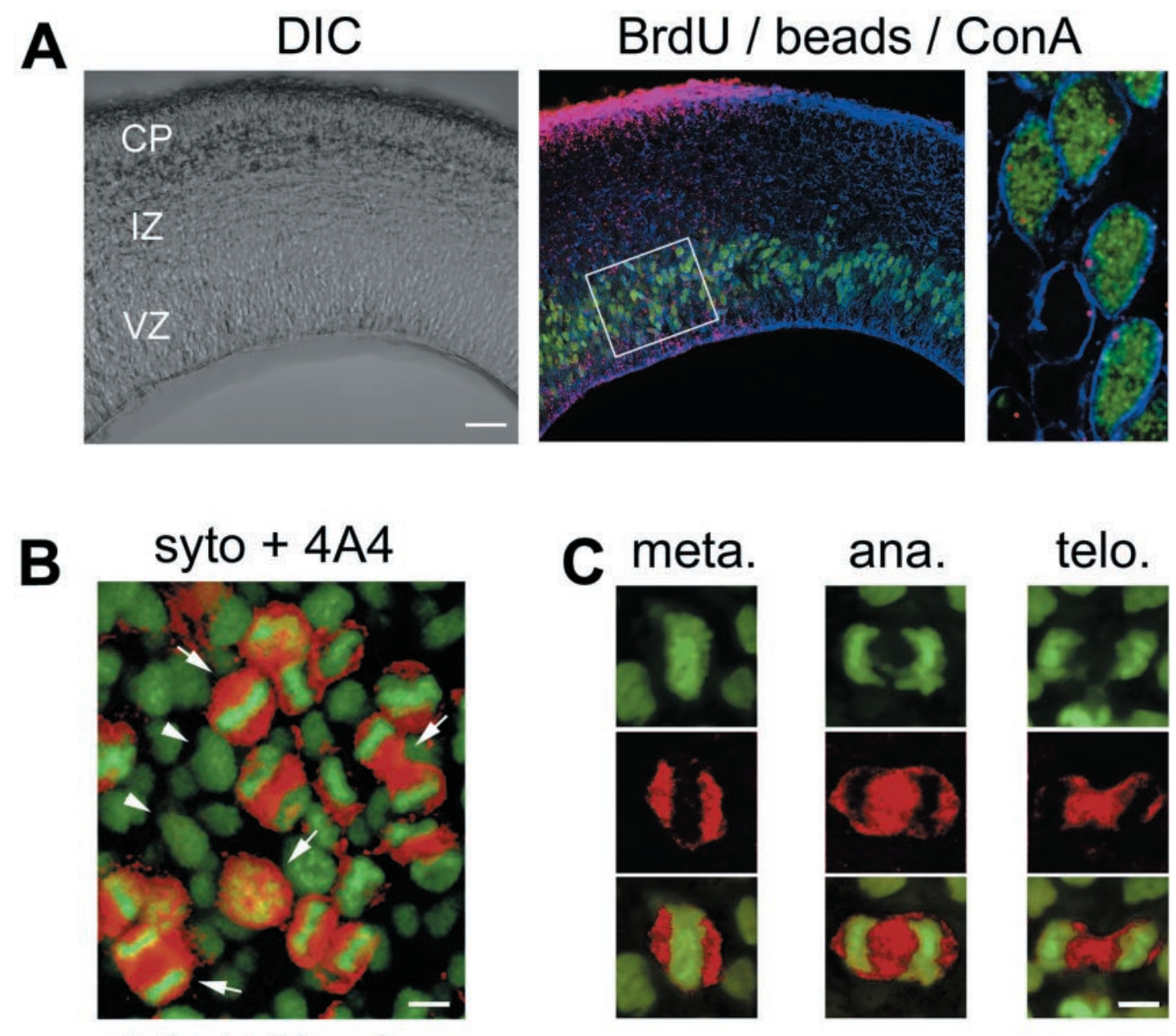

\section{Intact VZ surface}

D
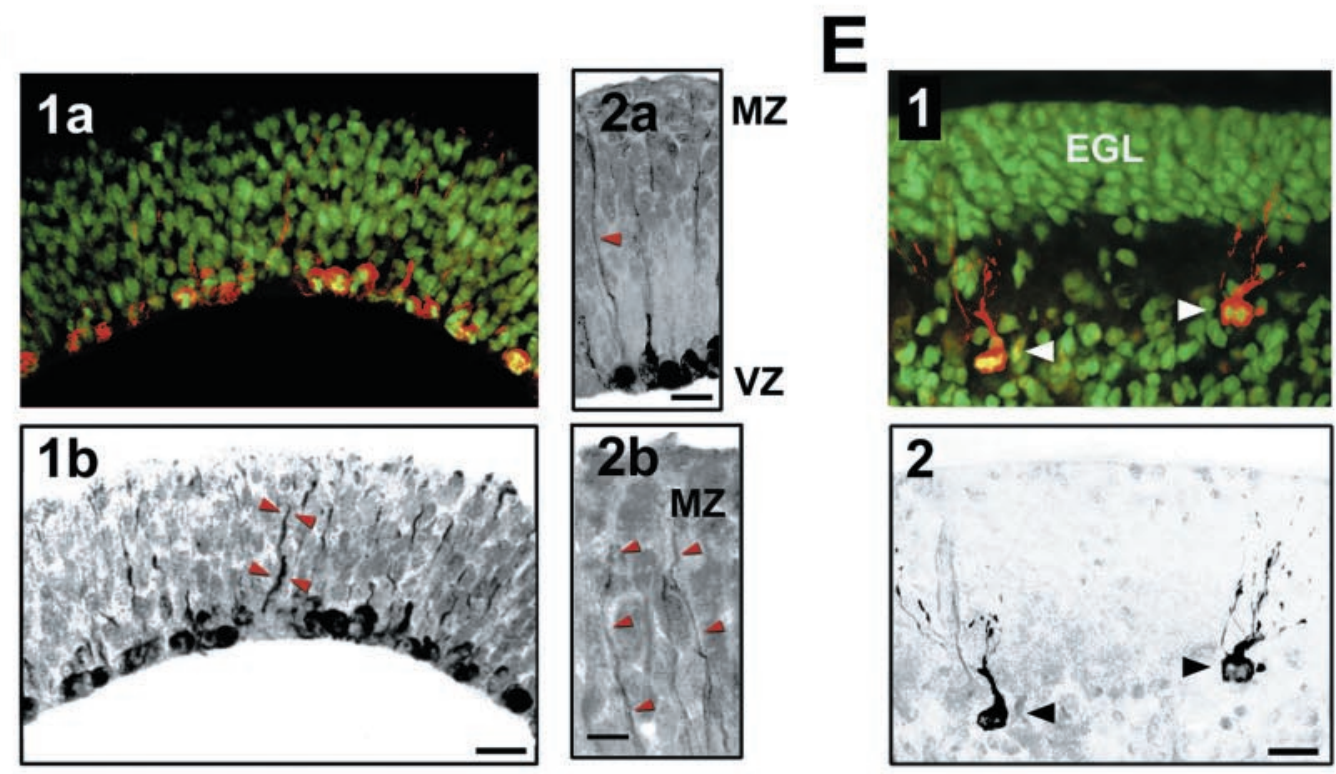

E15 Coronal section

P8 cerebellum

Figure 5. M-phase cells in the VZ express the radial glial marker 4A4, and cells in S-phase and M-phase have radial glial morphology. A, BrdU-positive cells (green) are labeled by fluorescent microspheres (beads, red) placed on the pia. Colabeling (shown at E17) is confirmed by ConA staining of cell borders (blue). Cells were analyzed in the VZ underlying pial bead application sites (box). Most BrdU-positive cells contain beads as shown in the right panel. B, Confocal sections of the ventricular surface from intact cortical slabs (shown at E15) demonstrate localization of 4A4 immunostaining (red) in cells identified as M-phase cells by the pattern of Syto-11 labeling (green). Arrows identify cells in different stages of (Figure legend continues.) 
Because radial glia self-renew (Levitt et al., 1981; Misson et al., 1988a), generate neurons (Malatesta et al., 2000; Noctor et al., 2001), and later transform into astrocytes (Schmechel and Rakic, 1979a; Misson et al., 1991), it may be most accurate to refer to them as bipotential or multipotential precursor cells. There may be restrictions on the diversity of neuronal and glial cell types generated by cortical radial glia. For example, neurons generated by radial glia in the cortical VZ may include only principal cells (pyramidal and projection neurons) rather than interneurons (Mione et al., 1997; Tan et al., 1998; Anderson et al., 1999). The glial cells generated by cortical radial glia may be restricted to the astrocytes into which they are thought to differentiate (Schmechel and Rakic, 1979a; Misson et al., 1991). However, it has been suggested that in mammals, some radial glial cells might also be the precursors for the major classes of adult glial cells, including oligodendrocytes as well as astrocytes (Choi and Kim, 1985; Hirano and Goldman, 1988; Rakic, 1995). It is also possible that there are subclasses of radial glial precursor cells (Schmechel and Rakic, 1979b; Qian et al., 1998; Hartfuss et al., 2001) with more or less restricted potential to act as neuronal or astrocytic progenitors. For example, the transcription factor genes Emx2 and Pax6 are expressed within precursor cells of the cortical VZ along two complementary gradients (Gulisano et al., 1996; Bishop et al., 2000; Muzio et al., 2002). These patterns may reflect expression of different transcription factors by radial glial cells in different proliferative regions. Such selective expression has been demonstrated for the transcription factor Pax6, which is expressed in radial glia of the cortex but not radial glia of the basal telencephalon (Götz et al., 1998),

\section{Radial glial cells and neuronal migration in the cortex}

Recently, lineage analysis experiments using chimeric embryos as well as retroviral labeling indicated that radially migrating cortical neurons are primarily projection neurons, whereas tangentially migrating neurons are primarily interneurons (Mione et al., 1997; Tan et al., 1998). Moreover, most of the tangentially migrating neurons appear to be inhibitory interneurons generated in the proliferative zone of the adjacent ganglionic eminence (Anderson et al., 1997; Wichterle et al., 1999), whereas the excitatory projection neurons are thought to migrate radially from the cortical VZ (Anderson et al., 1997; Mione et al., 1997; Tan et al., 1998). Thus there appear to be different proliferative zones for the generation of distinct classes of cortical neurons. We observe that after infection of radial glia in the VZ with a GFP-expressing retrovirus, many of the postnatal GFPexpressing cells in the cortex appear to be pyramidal neurons. This observation is consistent with the hypothesis that cortical radial glia may generate clones consisting primarily of pyramidal neurons.

Our anatomical labeling shows that most of the VZ cells have radial glial morphology, with both an endfoot on the ventricle and a long radial fiber extending toward the pia (Magini, 1888b; His,

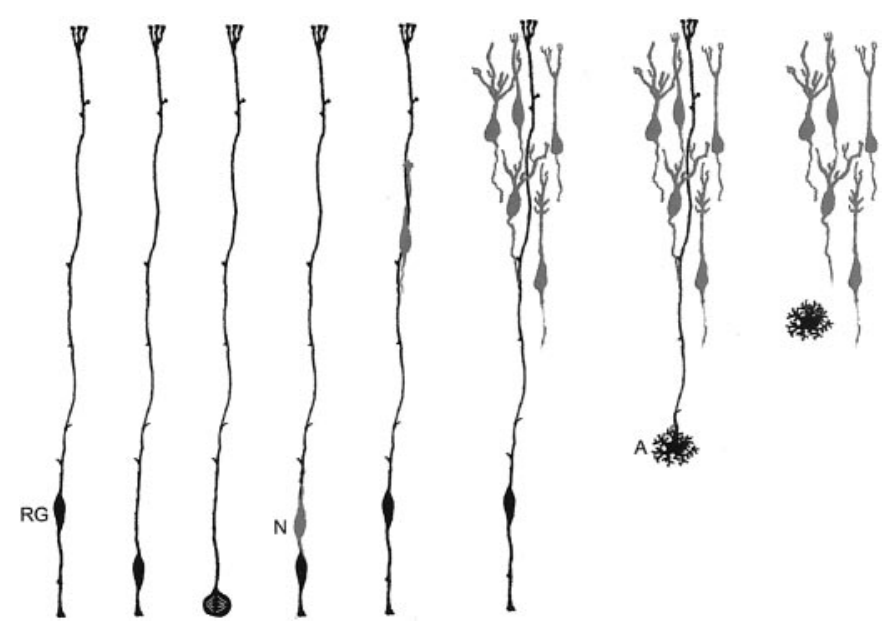

Figure 6. Schematic hypothesis for neuronal generation in the neocortex. Our model proposes that one population, the radial glial cell $(R G)$, both generates neurons and guides neuronal migration. Newborn neurons $(N)$ generated by radial glial precursor cells ascend along the radial fiber of the parental radial glial cell. A series of asymmetric radial glial cell divisions produces a clone of cortical pyramidal neurons. After neurogenesis, some radial glial cells transform into astrocytes $(A)$.

1889; Kölliker, 1896; Schmechel and Rakic, 1979a; for review, see Bentivoglio and Mazzarello, 1999). Until recently it was thought that only radial glial cells have this morphology. It has been suggested, however, that at early stages of neurogenesis some migrating neurons may resemble radial glia (Brittis et al., 1995; Nadarajah et al., 2001). A new time lapse study from Miyata et al. (2001) suggests that newborn neurons may span the width of the cortex by inheriting the morphology of their parent radial glial cell. This study indicates that production of neurons by radial glial cells is quite common, which supports our conclusion that most VZ precursor cells have radial glial characteristics. In addition, Miyata et al. (2001) suggest that radial glial cells have short radial processes transiently that re-extend after mitosis. These radial glia with processes that do not reach the pia may correspond to the "freely arborizing spongioblasts" described by Stensaas (1967). Other studies have also indicated heterogeneous radial glial fiber length during periods of neurogenesis (Gadisseux et al., 1992). One possible explanation is that some radial glial cells in $\mathrm{G}_{1}$-phase may have shorter regrowing processes after mitosis, whereas at subsequent cell cycle stages, S-, $\mathrm{G}_{2^{-}}$and $\mathrm{M}$-phase, radial glial fibers are full length. This interpretation is consistent with our observations of long fibers in some dividing cells. Although some newly generated postmitotic neurons may have been included with our radial glial counts in the DiOlistics experiments, we find no evidence that a separate population of mitotically active nonradial glial precursor cells exists in the VZ.

\footnotetext{
(Figure legend continued.) M-phase that are 4A4 positive. Arrowheads identify cells without condensed chromatin that are not in M-phase and do not express 4A4. $C$, Cells in specific stages of M-phase, including metaphase, anaphase, and telophase, are clearly identified by Syto-11 chromatin morphology ( green) and have surrounding 4A4 fluorescence (red). D1a, Overlay of Syto-11 (green) and 4A4 (red) fluorescence in a coronal section at E15. D1b, 4A4 staining in this same section (black) shows multiple cells labeled at the ventricular border and 4A4-positive radial fibers extending toward the pia (arrowheads). D2a, Radial processes of 4A4-positive cells (arrowhead) extend to the pia and marginal zone (MZ). D2b, Faint 4A4 labeling is present in distal fibers that reach the MZ (arrowheads). E1, Overlay of Syto-11 ( green) and 4A4 (red) in P8 cerebellum demonstrates colabeling in Bergmann radial glia (arrowheads). Granule cell precursors in the external granule layer $(E G L)$ do not express 4A4. E2, 4A4-positive staining (black) in the same section as E1 demonstrates morphology of M-phase Bergmann radial glia (arrowheads). Scale bars: $A, 100 \mu \mathrm{m} ; B, 5 \mu \mathrm{m} ; C, 4 \mu \mathrm{m} ; D 1, D 2 a, E, 10 \mu \mathrm{m} ; D 2 b, 5 \mu \mathrm{m}$.
} 


\section{Radial glial cells as neuronal precursor cells in adulthood and throughout the CNS}

Radial glial cells may play a role in neurogenesis in multiple CNS regions, in both development and adulthood. In the vertebrate retina, radial glial cells known as Müller glia have been suspected to be retinal precursor cells both during early development and during regeneration (Reh and Levine, 1998; Fischer and Reh, 2001). In the chick optic tectum, radial glia appear to generate radial clones of neurons during development (Gray and Sanes, 1992). At postnatal stages of cortical development, some radial glial cells transform into subventricular zone astrocytes (Schmechel and Rakic, 1979a), which in the adult have been shown to generate neurons that subsequently migrate into the olfactory bulb (Doetsch et al., 1999). In the dentate gyrus of the hippocampus, radial glia persist into adulthood in specific regions where adult neurogenesis occurs (Gould et al., 1997), and recently a link between hippocampal radial glia and adult neurogenesis has been suggested (Seri et al., 2001). In the adult avian ventricular zone, "hotspots" of dividing radial glia correspond to local regions of neurogenesis (Alvarez-Buylla et al., 1990). Thus radial glia may generate neurons in the adult nervous system as well as produce neurons during embryonic development.

Developmental insults can affect radial glia, migration, and neurogenesis. In utero radiation exposure during periods of peak neurogenesis disrupts neurogenesis and causes severe disruption of radial glia (Roper et al., 1997). Similarly, exposure to an antimitotic agent disrupts radial glial cells and impairs normal cortical layering (Noctor et al., 1999). In humans, developmental causes of cortical malformations such as heterotopias, lissencephaly, polymicrogyria, and related conditions have been interpreted to represent varying forms of neuronal migration disorders. However, in many of these conditions, there is evidence for greatly decreased neuronal numbers in addition to the failure of neurons to migrate to their appropriate destinations. Our finding that radial glia subserve both proliferation and migration may explain the apparent combination of proliferative and migrational defects in patients affected by these disorders. It remains to be seen, however, whether radial glia play the same roles in primate development that we have observed in rodent development.

\section{Conclusion}

Our findings expand the role of radial glia in neocortical development. The prevailing model for cortical neurogenesis and neuronal migration holds that a distinct population of precursors restricted to the $\mathrm{VZ}$ give rise to neurons that then migrate out of the $\mathrm{VZ}$ along nearby radial glial cells. The present data support a modified model in which radial glial neuronal precursor cells first generate neurons in the $\mathrm{VZ}$ and then guide the migration of their neuronal progeny into the cortex (Fig. 6). The centralization of neurogenesis and migrational guidance in one cell type expands the role of the cortical $\mathrm{VZ}$ precursor cell and provides an efficient mechanism for establishing the laminar and columnar organization of the developing neocortex. The sequential migration of clonally related neurons along the parent radial glia fiber enables related cells to take up positions in different cortical layers during the inside-out formation of the cortex as predicted by the radial unit hypothesis (Rakic, 1988). Mutual contact with the parental radial glial fiber (Noctor et al., 2001) may also allow for the formation of synaptic connections among neurons within the clone to form a local micronetwork across the cortical layers. Therefore the clonal relationship between radial glia and their neuronal daughter cells may underlie the establishment of local cortical circuitry to form functional radial units.

\section{REFERENCES}

Altman J, Bayer SA (1990) Vertical compartmentation and cellular transformations in the germinal matrices of the embryonic rat cerebral cortex. Exp Neurol 107:23-35.

Alvarez-Buylla A, Buskirk DR, Nottebohm F (1987) Monoclonal antibody reveals radial glia in adult avian brain. J Comp Neurol 264:159-170

Alvarez-Buylla A, Theelen M, Nottebohm F (1990) Proliferation "hot spots" in adult avian ventricular zone reveal radial cell division. Neuron 5:101-109.

Alvarez-Buylla A, Garcia-Verdugo JM, Tramontin AD (2001) A unified hypothesis on the lineage of neural stem cells. Nat Rev Neurosci 2:287-293.

Anderson S, Mione M, Yun K, Rubenstein JL (1999) Differential origins of neocortical projection and local circuit neurons: role of Dlx genes in neocortical interneuronogenesis. Cereb Cortex 9:646-654.

Anderson SA, Eisenstat DD, Shi L, Rubenstein J (1997) Interneuron migration from basal forebrain to neocortex: dependence on dlx genes. Science 278:474-476.

Angevine JBJ, Sidman RL (1961) Autoradiographic study of cell migration during histogenesis of cerebral cortex in the mouse. Nature 192:766-768.

Bentivoglio M, Mazzarello P (1999) The history of radial glia. Brain Res Bull 49:305-315.

Bishop KM, Goudreau G, O'Leary DD (2000) Regulation of area identity in the mammalian neocortex by Emx2 and Pax6. Science 288:344-349.

Bittman K, Owens DF, Kriegstein AR, LoTurco JJ (1997) Cell coupling and uncoupling in the ventricular zone of developing neocortex. J Neurosci 17:7037-7044.

Blanton MG, LoTurco JJ, Kriegstein AR (1989) Whole cell recording from neurons in slices of reptilian and mammalian cerebral cortex J Neurosci Methods 30:203-210.

Boulder Committee (1970) Embryonic vertebrate central nervous system: revised terminology. Anat Rec 166:257-261.

Brittis PA, Meiri K, Dent E, Silver J (1995) The earliest patterns of neuronal differentiation and migration in the mammalian central nervous system. Exp Neurol 134:1-12.

Bruckner G, Biesold D (1981) Histochemistry of glycogen deposition in perinatal rat brain: importance of radial glial cells. J Neurocytol $10: 749-757$

Chanas-Sacre G, Rogister B, Moonen G, Leprince P (2000) Radial glia phenotype: origin, regulation, and transdifferentiation. J Neurosci Res 61:357-363.

Choi BH, Kim RC (1985) Expression of glial fibrillary acidic protein by immature oligodendroglia and its implications. J Neuroimmunol $8: 215-235$.

Dahl D, Rueger DC, Bignami A, Weber K, Osborn M (1981) Vimentin, the 57,000 molecular weight protein of fibroblast filaments, is the majo cytoskeletal component in immature glia. Eur J Cell Biol 24:191-196.

Doetsch F, Caille I, Lim DA, Garcia-Verdugo JM, Alvarez-Buylla A (1999) Subventricular zone astrocytes are neural stem cells in the adult mammalian brain. Cell 97:703-716.

Feng L, Hatten ME, Heintz N (1994) Brain lipid-binding protein (BLBP): a novel signaling system in the developing mammalian CNS Neuron 12:895-908.

Fischer AJ, Reh TA (2001) Muller glia are a potential source of neural regeneration in the postnatal chicken retina. Nat Neurosci 4:247-252.

Gadisseux JF, Evrard P, Mission JP, Caviness Jr VS (1992) Dynamic changes in the density of radial glial fibers of the developing murine cerebral wall: a quantitative immunohistological analysis. J Comp Neurol 322:246-254

Gan WB, Grutzendler J, Wong WT, Wong RO, Lichtman JW (2000) Multicolor "DiOlistic" labeling of the nervous system using lipophilic dye combinations. Neuron 27:219-225.

Geisert Jr EE, Frankfurter A (1989) The neuronal response to injury as visualized by immunostaining of class III beta-tubulin in the rat. Neurosci Lett 102:137-141.

Golgi C (1886) Sulla fina anatomia degli organi centrali del sistema nervoso. Milano: Hoepli.

Götz M, Stoykova A, Gruss P (1998) Pax6 controls radial glia differentiation in the cerebral cortex. Neuron 21:1031-1044.

Gould E, McEwen BS, Tanapat P, Galea LA, Fuchs E (1997) Neurogenesis in the dentate gyrus of the adult tree shrew is regulated by psychosocial stress and NMDA receptor activation. J Neurosci 17:2492-2498.

Gray GE, Sanes JR (1992) Lineage of radial glia in the chicken optic tectum. Development 114:271-283.

Gulisano M, Broccoli V, Pardini C, Boncinelli E (1996) Emx1 and Emx2 show different patterns of expression during proliferation and differen- 
tiation of the developing cerebral cortex in the mouse. Eur J Neurosci 8:1037-1050

Hartfuss E, Galli R, Heins N, Götz M (2001) Characterization of CNS precursor subtypes and radial glia. Dev Biol 229:15-30.

Hatten ME (1999) Central nervous system neuronal migration. Annu Rev Neurosci 22:511-539.

Hatten ME, Heintz N (1995) Mechanisms of neural patterning and specification in the developing cerebellum. Annu Rev Neurosci 18:385-408.

Hirano M, Goldman JE (1988) Gliogenesis in rat spinal cord: evidence for origin of astrocytes and oligodendrocytes from radial precursors. J Neurosci Res 21:155-167.

His W (1889) Die Neuroblasten und deren Entstehung im embryonalen Mark. Abh Kgl sachs Ges Wissensch math phys K1 15:311-372.

Hockfield S, McKay RD (1985) Identification of major cell classes in the developing mammalian nervous system. J Neurosci 5:3310-3328.

Hofmann MH, Bleckmann H (1999) Effect of temperature and calcium on transneuronal diff usion of DiI in fixed brain preparations. J Neurosci Methods 88:27-31.

Kalman M, Ajtai BM (2001) A comparison of intermediate filament markers for presumptive astroglia in the developing rat neocortex: mmunostaining against nestin reveals more detail than GFAP or vimentin. Int J Dev Neurosci 19:101-108.

Kamei Y, Inagaki N, Nishizawa M, Tsutsumi O, Taketani Y, Inagaki M (1998) Visualization of mitotic radial glial lineage cells in the developing rat brain by $\mathrm{Cdc} 2$ kinase-phosphorylated vimentin. Glia 23:191-199.

Katz LC, Burkhalter A, Dreyer WJ (1984) Fluorescent latex microspheres as a retrograde neuronal marker for in vivo and in vitro studies of visual cortex. Nature 310:498-500.

Kölliker A (1896) Handbuch der Gewebelehre des Menschen, Ed 6. Leipzig: W. Engleman.

Lendahl U, Zimmerman LB, McKay RD (1990) CNS stem cells express a new class of intermediate filament protein. Cell 60:585-595.

Levitt P, Rakic P (1980) Immunoperoxidase localization of glial fibrillary acidic protein in radial glial cells and astrocytes of the developing rhesus monkey brain. J Comp Neurol 193:815-840.

Levitt P, Cooper ML, Rakic P (1981) Coexistence of neuronal and glial precursor cells in the cerebral ventricular zone of the fetal monkey: an ultrastructural immunoperoxidase analysis. J Neurosci 1:27-39.

Levitt P, Cooper ML, Rakic P (1983) Early divergence and changing proportions of neuronal and glial precursor cells in the primate cerebral ventricular zone. Dev Biol 96:472-484

LoTurco JJ, Kriegstein AR (1991) Clusters of coupled neuroblasts in embryonic neocortex. Science 252:563-566.

LoTurco JJ, Owens DF, Heath MJS, Davis MBE, Kriegstein AR (1995) GABA and glutamate depolarize cortical progenitor cells and inhibit DNA synthesis. Neuron 15:1287-1298.

Magini G (1888a) Sur la neuroglie et les cellules nerveuses cerebrales chez les foetus. Arch Ital Biol 9:59-60.

Magini J (1888b) Nouvelles recherches histologiques sur le cerveau du foetus. Arch Ital Biol 10:384-387.

Malatesta P, Hartfuss E, Götz M (2000) Isolation of radial glial cells by fluorescent-activated cell sorting reveals a neuronal lineage. Development 127:5253-5263.

Massa PT, Mugnaini E (1982) Cell junctions and intramembrane particles of astrocytes and oligodendrocytes: a freeze-fracture study. Neuroscience 7:523-538

Mione MC, Cavanagh JFR, Harris B, Parnavelas JG (1997) Cell fate specification and symmetrical/asymmetrical divisions in the developing cerebral cortex. J Neurosci 17:2018-2029.

Misson JP, Edwards MA, Yamamoto M, Caviness Jr VS (1988a) Mitotic cycling of radial glial cells of the fetal murine cerebral wall: a combined autoradiographic and immunohistochemical study. Brain Res 466:183-190.

Misson JP, Edwards MA, Yamamoto M, Caviness Jr VS (1988b) Identification of radial glial cells within the developing murine central nervous system: studies based upon a new immunohistochemical marker. Brain Res Dev Brain Res 44:95-108.

Misson JP, Takahashi T, Caviness VS Jr (1991) Ontogeny of radial and other astroglial cells in murine cerebral cortex. Glia 4:138-148.

Miyata T, Kawaguchi A, Okano H, Ogawa M (2001) Asymmetric inheritance of radial glial fibers by cortical neurons. Neuron 31:727-741.

Muzio L, DiBenedetto B, Stoykova A, Boncinelli E, Gruss P, Mallamaci A (2002) Emx2 and Pax6 control regionalization of the preneuronogenic cortical primordium. Cereb Cortex 12:129-139.

Nadarajah B, Brunstrom JE, Grutzendler J, Wong RO, Pearlman AL (2001) Two modes of radial migration in early development of the cerebral cortex. Nat Neurosci 4:143-150.
Noctor SC, Palmer SL, Hasling T, Juliano SL (1999) Interference with the development of early generated neocortex results in disruption of radial glia and abnormal formation of neocortical layers. Cereb Cortex 9:121-136.

Noctor SC, Flint AC, Weissman TA, Dammerman RS, Kriegstein AR (2001) Neurons derived from radial glial cells establish radial units in neocortex. Nature 409:714-720.

O'Rourke NA, Chenn A, McConnell SK (1997) Postmitotic neurons migrate tangentially in the cortical ventricular zone. Development 124:997-1005

Parnavelas JG, Nadarajah B (2001) Radial glial cells. Are they really glia? Neuron 31:881-884.

Pixley SK, de Vellis J (1984) Transition between immature radial glia and mature astrocytes studied with a monoclonal antibody to vimentin. Brain Res 317:201-209.

Qian X, Goderie SK, Shen Q, Stern JH, Temple S (1998) Intrinsic programs of patterned cell lineages in isolated vertebrate CNS ventricular zone cells. Development 125:3143-3152.

Rakic P (1971a) Guidance of neurons migrating to the fetal monkey neocortex. Brain Res 33:471-476.

Rakic P (1971b) Neuron-glia relationship during granule cell migration in developing cerebellar cortex. A Golgi and electron microscopic study in Macacus Rhesus. J Comp Neurol 141:283-312.

Rakic P (1972) Mode of cell migration to the superficial layers of fetal monkey neocortex. J Comp Neurol 145:61-83.

Rakic P (1978) Neuronal migration and contact guidance in the primate telencephalon. Postgraduate Medical J 1:25-40.

Rakic P (1988) Specification of cerebral cortical areas. Science 241:170-176.

Rakic P (1995) Radial gial cells: scaffolding for brain construction. In: Neuroglia (Kettenmann H, Ransom BR, eds), pp 746-762. Oxford: Oxford UP.

Ramón y Cajal S (1911) Histologie du système nerveux de l'hommes et des vertébrés. Paris: Maloine.

Ramón y Cajal S (1995) Histology of the nervous system. Oxford: Oxford UP.

Reh TA, Levine EM (1998) Multipotential stem cells and progenitors in the vertebrate retina. J Neurobiol 36:206-220.

Retzius G (1894) Die Neuroglia des Gehirns beim Menschen und bei Säugetieren. Biologische Untersuchungen 6:1-24

Roper SN, Abraham LA, Streit WJ (1997) Exposure to in utero irradiation produces disruption of radial glia in rats. Dev Neurosci $19: 521-528$

Sauer FC (1935) Mitosis in the neural tube. J Comp Neurol 62:377-405

Schmechel DE, Rakic P (1979a) A Golgi study of radial glial cells in developing monkey telencephalon: morphogenesis and transformation into astrocytes. Anat Embryol 156:115-152.

Schmechel DE, Rakic P (1979b) Arrested proliferation of radial glial cells during midgestation in rhesus monkey. Nature 277:303-305.

Seri B, Garcia-Verdugo JM, McEwen BS, Alvarez-Buylla A (2001) Astrocytes give rise to new neurons in the adult mammalian hippocampus. J Neurosci 21:7153-7160.

Shibata T, Yamada K, Watanabe M, Ikenaka K, Wada K, Tanaka K, Inoue Y (1997) Glutamate transporter GLAST is expressed in the radial glia-astrocyte lineage of developing mouse spinal cord. J Neurosci 17:9212-9219.

Stensaas LJ (1967) The development of hippocampal and dorsolatera pallial regions of the cerebral hemisphere in fetal rabbits. 3. Fifteen millimeter stage, spongioblast morphology. J Comp Neurol 129:59-70.

Takahashi T, Nowakowski RS, Caviness Jr VS (1996) Interkinetic and migratory behavior of a cohort of neocortical neurons arising in the early embryonic murine cerebral wall. J Neurosci 16:5762-5776.

Tamamaki N, Nakamura K, Okamoto K, Kaneko T (2001) Radial glia is a progenitor of neocortical neurons in the developing cerebral cortex. Neurosci Res 41:51-60.

Tan SS, Kalloniatis M, Sturm K, Tam PP, Reese BE, Faulkner-Jones B (1998) Separate progenitors for radial and tangential cell dispersion during development of the cerebral neocortex. Neuron 21:295-304.

Tarasova NI, Stauber RH, Choi JK, Hudson EA, Czerwinski G, Miller JL, Pavlakis GN, Michejda CJ, Wank SA (1997) Visualization of G protein-coupled receptor trafficking with the aid of the green fluorescent protein. Endocytosis and recycling of cholecystokinin receptor type A. J Biol Chem 272:14817-14824.

Voigt T (1989) Development of glial cells in the cerebral wall of ferrets: direct tracing of their transformation from radial glia into astrocytes. J Comp Neurol 289:74-88.

Wichterle H, Garcia-Verdugo JM, Herrera DG, Alvarez-Buylla A (1999) Young neurons from medial ganglionic eminence disperse in adult and embryonic brain. Nat Neurosci 2:461-466. 